\title{
Genotype-phenotype specificity in Menke-Hennekam syndrome caused by missense variants in exon 30 or 31 of CREBBP
}

DOI:

10.1002/ajmg.a.61131

\section{Document Version}

Accepted author manuscript

Link to publication record in Manchester Research Explorer

Citation for published version (APA):

Banka, S., Sayer, R., Breen, C., Barton, S., Pavaine, J., Sheppard, S. E., Bedoukian, E., Skraban, C., Cuddapah, V. A., \& Clayton-Smith, J. (2019). Genotype-phenotype specificity in Menke-Hennekam syndrome caused by missense variants in exon 30 or 31 of CREBBP. American Journal of Medical Genetics. Part A.

https://doi.org/10.1002/ajmg.a.61131

Published in:

American Journal of Medical Genetics. Part A

\section{Citing this paper}

Please note that where the full-text provided on Manchester Research Explorer is the Author Accepted Manuscript or Proof version this may differ from the final Published version. If citing, it is advised that you check and use the publisher's definitive version.

\section{General rights}

Copyright and moral rights for the publications made accessible in the Research Explorer are retained by the authors and/or other copyright owners and it is a condition of accessing publications that users recognise and abide by the legal requirements associated with these rights.

\section{Takedown policy}

If you believe that this document breaches copyright please refer to the University of Manchester's Takedown Procedures [http://man.ac.uk/04Y6Bo] or contact uml.scholarlycommunications@manchester.ac.uk providing relevant details, so we can investigate your claim.

\section{OPEN ACCESS}




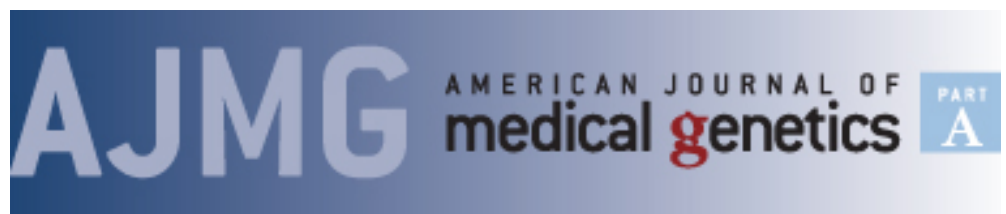

\section{Genotype-phenotype specificity in Menke-Hennekam syndrome caused by missense variants in exon 30 or 31 of CREBBP}

\begin{tabular}{|c|c|}
\hline Journal: & American Journal of Medical Genetics: Part A \\
\hline Manuscript ID & 19-0040.R1 \\
\hline Wiley - Manuscript type: & Clinical Report \\
\hline $\begin{array}{r}\text { Date Submitted by the } \\
\text { Author: }\end{array}$ & $\mathrm{n} / \mathrm{a}$ \\
\hline Complete List of Authors: & $\begin{array}{l}\text { Banka, Siddharth; University of Manchester, Manchester Centre for } \\
\text { Genomic Medicine } \\
\text { Sayer, Rebecca; St Mary's Hospital } \\
\text { Breen, Catherine; St Mary's Hospital } \\
\text { Barton, Stephanie; SMH } \\
\text { Pavaine, Julija; MFT } \\
\text { Sheppard, Sarah; Children's Hospital of Philadelphia, Division of Human } \\
\text { Genetics } \\
\text { Bedoukian, Emma ; The Children's Hospital of Philadelphia, Philadelphia, } \\
\text { Roberts Individualized Medical Genetics Center } \\
\text { Skraban, Cara; Children's Hospital of Philadelphia, Human Genetics } \\
\text { Cuddapah, Vishnu; Children's Hospital of Philadelphia } \\
\text { Clayton-Smith, Jill; Manchester Centre for Genomic Medicine, Saint } \\
\text { Mary's Hospital, Oxford Road; Division of Evolution and Genomic } \\
\text { Sciences, School of Biological Sciences, University of Manchester }\end{array}$ \\
\hline Keywords: & CREBBP, Menke-Hennekam syndrome, Rubinstein-Taybi syndrome \\
\hline Search Terms: & \\
\hline
\end{tabular}

\section{SCHOLARONE" Manuscripts}




\section{Genotype-phenotype specificity in Menke-Hennekam syndrome caused by missense variants in exon 30 or 31 of $C R E B B P$}

Siddharth Banka ${ }^{1,2}$, Rebecca Sayer ${ }^{2}$, Catherine Breen ${ }^{1,2}$, Stephanie Barton ${ }^{2}$, Julija Pavaine ${ }^{3,4}$, Sarah E. Sheppard ${ }^{5}$, Emma Bedoukian6, Cara Skraban,7, Vishnu A Cuddapah ${ }^{8}$, Jill Clayton-Smith ${ }^{1,2}$

1. Division of Evolution \& Genomic Sciences, School of Biological Sciences, Faculty of Biology, Medicine and Health, University of Manchester, Manchester M13 9WL, UK.

2. Manchester Centre for Genomic Medicine, St Mary's Hospital, Manchester University NHS Foundation Trust, Health Innovation Manchester, Manchester M13 9WL, UK.

3. Academic Unit of Paediatric Radiology, Royal Manchester Children's Hospital, Manchester University Hospitals NHS Foundation Trust, Manchester Academic Health Sciences Centre, Manchester, UK

4. Division of Informatics, Imaging \& Data Sciences, School of Health Sciences, Faculty of Biology, Medicine and Health, University of Manchester, Manchester Academic Health Science Centre, Manchester, UK

5. Division of Human Genetics, Children's Hospital of Philadelphia, Philadelphia, PA. USA.

6. Roberts Individualized Medical Genetics Center, Children's Hospital of Philadelphia, Philadelphia, PA. USA.

7. Department of Pediatrics, Perelman School of Medicine, University of Pennsylvania Perelman School of Medicine

8. Division of Neurology, Children's Hospital of Philadelphia, Philadelphia, PA. USA.

\section{Correspondence:}

Dr Siddharth Banka

Manchester Centre for Genomic Medicine, Saint Mary's Hospital, Oxford Road, Manchester. M13 9WL. U.K. 
Tel: +44 (0) 16170 10980; Fax: +44 (0) 16127 66145; siddharth.banka@manchester.ac.uk

\begin{abstract}
CREBBP loss-of function variants cause Rubinstein-Taybi syndrome (RTS). There have been two separate reports of patients with missense variants in exon 30 or 31 of $C R E B B P$ in individuals lacking the characteristic facial and limb dysmorphism associated with RTS. Frequent features in this condition include variable intellectual disability, short stature, autistic behavior, microcephaly, feeding problems, epilepsy, recurrent upper airway infections and mild hearing impairment.
\end{abstract}

We report three further patients with de novo exon 31 CREBBP missense variants. The first individual has a c.5357G>A p. (Arg1786His) variant affecting the same codon as one of the previously described patients. Both these patients could be recognized by clinicians as mild RTS. Our second patient has a c.5602C $>\mathrm{T}$ p.(Arg1868Trp) variant that has been described in five other individuals who all share a strikingly similar phenotype. The third individual has a novel c.5354G>A p.(Cys1785Try) variant.

Our reports expand the clinical spectrum to include ventriculomegaly, absent corpus callosum, staphyloma, cochlear malformations, and exomphalos. These additional cases also help to establish genotype- phenotype correlations in this disorder. After the first and last authors of the previous two reports, we propose to call this disorder 'Menke-Hennekam syndrome' to establish it as a clinical entity distinct from RTS and to provide a satisfactory name for adoption by parents and professionals, thus facilitating appropriate clinical management and research.

\author{
KEYWORDS \\ Menke-Hennekam syndrome \\ RubensteinRubinstein-Taybi syndrome \\ CREBBP
}




\section{MAIN TEXT}

\section{Introduction}

CREBBP (OMIM 600140) encodes CREB-binding protein, heterozygous loss of function variants in which cause Rubinstein-Taybi syndrome type 1 (RTS1, OMIM 180849) which is characterized by developmental delay, intellectual disability, microcephaly, growth deficiency [Petrif et al., 1995] [Hennekam, 2006; Wiley et al., 2003]. The main distinguishing features of RTS include facial dysmorphism (high arched eyebrows, down slanting palpebral fissures, a convex nasal ridge and low hanging columella), a characteristic grimacing smile and broad thumbs and halluces.

Recently Menke et al. reported 10 distinct de novo missense variants between base pairs 5,128 and 5,614 (NM_004380.2) affecting 9 distinct codons (between codon numbers 1,710 and 1,872) in the 3' end (last) part of exon 30 or 5' end (beginning) of exon 31 of $C R E B B P$ in 11 patients [Menke et al., 2016]. The phenotypes of these patients were not (or only to a limited extent) concordant with RTS. Subsequently, the same group published an additional 11 patients within the same region [Menke et al., 2018]. Here we report three further children with exon 31 missense CREBBP variants without the typical RTS features.

\section{Case Reports}

Patient \#1 is a male aged 5 years is the fourth child of non-consanguineous Caucasian parents born at 42 weeks gestation, following an unremarkable pregnancy with a birth weight of $3.23 \mathrm{~kg}$ (9th-25th centile). At birth, his feet were noted to be in-turned from the mid foot. Feeding difficulties were noted shortly after birth. He sat unsupported at 12 months, crawled at 13 months and walked independently at 18 months of age. His speech was delayed and at 3 years 3 month he had only four words. His language comprehension is also poor. There are no concerns about his hearing and vision. He has stereotypic behaviour including repetitive spinning and hand flapping movements, but is sociable and interactive. At 3 years and 3 months he was small for his age and for his family - height $90.2 \mathrm{~cm}(2 \mathrm{nd}$ 
centile; -3SD); weight $12.7 \mathrm{~kg}$ (2nd-9th centile; -3SD); OFC 48.5cm (0.4th-2nd centile; -3SD). When reviewed at 3 years and 11 months he was noted to have an area of alopecia on his scalp. He had generalised joint laxity and bilateral metatarsus varus. He is brachycephalic, has a hirsute back and had needed correction for cryptorchidism. He had some self-injurious behavior and tended to bite the ends of his fingers but was otherwise very happy and sociable. He had made no further progress with his speech and communicated by signing. Testing on the Wechsler Preschool and Primary Scale of Intelligence revealed a composite score of 45 (range 90-119) for verbal comprehension. Tests of his visual spatial ability revealed that he was functioning just below the average level in this area. Formal testing did not reveal any abnormalities. His facial features at that stage suggested a possible clinical diagnosis of a Rubinstein-Taybi-like syndrome (Figure 1A,B), though he did not have any of the characteristic thumb or hallux abnormalities associated with RTS.

Sanger sequencing for $C R E B B P$ was not available locally. A clinical array-comparative genomic hybridisation (aCGH) did not identify any plausible pathogenic variants. SureSelectXT (Agilent) was used for Focused Exome enrichment and sequencing was performed on the NextSeq500 (Illumina), according to manufacturer's protocols. Variant calling was performed using samtools v0.1.18, with hg19 human genome as a reference, and variants were analysed using Sapientia v1.5 (Congenica) as described previously [Stoyle et al., 2018]. A heterozygous exon 31 missense $C R E B B P$ c.5357G>A p. (Arg1786His) (NM_004380.2) variant was identified in this patient. Subsequent parental targeted Sanger sequencing studies proved de novo origin of the variant.

Patient \#2 (female) is the first child of non-consanguineous Caucasian parents. Antenatal scans detected a ventricular septal defect and bilateral hydronephosis. She was delivered by forceps at 38 weeks and 3 days of gestation with a birth weight of $2.69 \mathrm{~kg}$ (9th centile) and head circumference of $30.6 \mathrm{~cm}$ (0.4th centile). After delivery she was noted to have facial dysmorphism, exomphalos, clitoromegaly, a large sacral dimple, long clenched fingers, long toes and bilateral fixed talipes (Figure 1C). Subsequently she was found to have profound hearing loss, visual impairment, poor feeding and 
severe gastro-oesophageal reflux requiring gastrostomy and fundoplication, scoliosis, dystonia and cutis marmorata (Table 1). Brain magnetic resonance imaging (MRI) obtained at 4 months of age showed abnormal corpus callosum, bilateral underdeveloped cochlear hypoplasia-and hypoplastic cochlear nerves (Figure 1E, F, G). A cochlear implant was inserted at the age of 18 months. At last review at the age of 20 months, the patient was sitting unsupported and pulling to stand. She was vocalising, but had no words. She had begun to exhibit self-injurious behaviour, hitting her head with her fists. There were also episodes of dystonic posturing, which are being treated with baclofen (Table $1)$.

A clinical aCGH was performed on amniotic fluid during pregnancy, which was normal. The focused clinical exome, as described for patient 1 , for syndromic intellectual disability was performed postnatally and revealed a heterozygous exon 31 CREBBP c.5602C > T p.(Arg1868Trp) missense variation. Subsequent parental targeted Sanger sequencing studies proved de novo origin of the variant.

Patient \# 3 (female) was the product of a 41-week gestation complicated by reported maternal CMV infection and decreased fetal movement. At delivery in Algeria, she weighed $2.2 \mathrm{~kg}$ (Z-2.53), had microcephaly, hemangiomas on the back, abdomen, and head, leg stiffening and clenched hands. She spent one week in the NICU for feeding difficulties and emesis. She was readmitted at 4 months of age with diarrhea and dehydration and was found to have a positive blood test for CMV. However, brain MRI obtained at 25 months of age did not show any intracranial calcifications or abnormal parenchymal signal to suggest sequela of CMV. Brain MRI showed possible bilateral staphylomas (protrusion of the uveal tissue through the eyeball), slight dysmorphism of the corpus callosum, and under-rotated hippocampi (Figure 1H). Ophthalmology evaluation did not show sequela of CMV but suggested central visual impairment. Staphylomas were not noted on Ophthalmology exam, but she was also not fully cooperative. Mother reported previous echocardiogram and renal bladder ultrasound was normal. At 25 months, she had significant failure to thrive, severe malnutrition, and 
chronic emesis secondary to loose esophageal sphincter. Her physical exam showed small growth parameters with head circumference most striking, mild hirsutism, full brows and lashes, dysconjugate gaze, bulbous nasal tip with smaller nares and mildly low columella, abnormal tone, and talipes varus with overlapping toes (Figure $1 \mathrm{D}$ ). She is now 3 years and 4 months old. She continues with feeding difficulties and remains G-tube fed with supplementation of pureed foods by mouth. There are no concerns for seizures. She has not had any regression and continues to make developmental progress. She can sit independently, grasp and transfer objects, and has no words but is babbling "dadada". Audiology evaluation showed normal hearing sensitivity in both ears at $2000 \mathrm{~Hz}$, with mild conductive hearing loss at thresholds of $4000 \mathrm{~Hz}$, possibly due to the presence of a PE tubes. SNP array performed for the patient was normal. Trio exome sequencing identified a de novo variant c.5354G>A p.(Cys1785Try) in exon 31 of $C R E B B P$.

\section{DISCUSSION}

Recent discoveries have expanded our knowledge of diverse phenotypes driven by dissimilar molecular and cellular consequences resulting from different class of variants in the same gene [Cuvertino et al., 2017; Reijnders et al., 2017; Martinelli et al., 2018]. CREBBP encodes a histone acetyl transferase and is a transcriptional activator that interacts with several other transcription factors and proteins [Dutto et al., 2018]. Overall, the features of these three patients are consistent with the recently described cohort (Table 1) [Menke et al., 2016, 2018]. Including this paper, there are now 25 patients reported in the medical literature without the typical RTS features and exon 30/31 missense CREBBP variants. The functional basis of 'exon 30 and 31 missense variant related non-RTS phenotypes' needs elucidation but Menke et al hypothesized disturbed protein-protein interactions by altered zinc finger function to be the underlying reason [Menke et al., 2016].

The c.5357G>A p. (Arg1786His) variant in our patient \#1 is a novel variant but affects the same codon that was affected by the variant in patient \#3 [c.5357G>C p. (Arg1786Pro)] reported in the first paper who was a 10y old boy with severe developmental delay and autism like behaviour [Menke et al., 
2016]. Photographs of Patient \#3 were not published but the affected child was reported to have down slanting palpebral fissures, long eye lashes, squint, convex nasal bridge, broad nasal tip, low hanging columella, high palate, micro- or retrognathia, protruding ears, fibular deviation of distal phalanx halluces and possibly broad halluces. Similar to our patient \#1, these features of patient \#3 reported by Menke et al. shares some features of RTS. Interestingly, all the patients in the first series were diagnosed via exome sequencing, apart from patient \#3, who was diagnosed by Sanger sequencing. His facial features at that stage suggested a possible clinical diagnosis of a RubinsteinTaybi-like syndrome. We had also noticed RTS-like facial features of our patient \#1. These observations suggest that patients with the variants affecting the p.Arg1786 codon may be more RTSlike than other patients with exon 30/31 CREBBP missense variants.

The c.5602C $>$ T p.(Arg1868Trp) variant in our patient \#2 is identical to the variant in patients \#9 (4y old female) and \#10 (0.8 years old female) in the first report [Menke et al., 2016], and C17 (2y old male), C18 (4y old male), C19 (1y old female) in the latter report [Menke et al., 2018]. An additional patient C20 (8y old male) was reported with a different substitution in the same codon [c.5603G>A (p.Arg1868Gln)] [Menke et al., 2018]. Most of these patients were reported to have severe developmental delay, microcephaly, telecanthus, short upturned palpebral fissures, ptosis, depressed nasal bridge, short nose, short columella, anteverted nares, long deep philtrum, low-set ears with protruding upper part and fibular deviation of distal phalanx halluces. The similarity in the facial dysmorphism of these three patients is strikingly similar and is not reminiscent of RTS at all (Figure 1). The facial features of our patient also resemble patient C21 in Menke et al. 2018 who has a different variant predicted to substitute a nearby amino acid (p.Ala1870Pro). In our patient \#2 we detected hypoplastic acoustic nerves and malformation of the cochlea. These features were not reported in other patients with the p.(Arg1868Trp) CREEBP variant although SNHL has been described. Importantly, most patients with other 9 exon 30/31 CREBBP missense variants have either normal hearing or mild-moderate conductive hearing loss. The six p.(Arg1868Trp) patients are amongst the most severely affected amongst the 25 patients described so far. These observations 
suggest that patients with the p.(Arg1868Trp) $C R E B B P$ variant constitute a distinct phenotype-group within patients with exon 30/31 CREBBP missense variants.

The c.5354G>A p.(Cys1785Try) CREBBP variant in our patient \#3 is a novel change. It is the adjacent amino acid residue to Arg1786 substituted in our Patient \#1. Notably she had bilateral staphylomas on imaging, which is not a previously reported feature of this condition. Similar to the patients previously described, she has global developmental delay and feeding difficulties. The delayed tooth eruption was described in patient C13 [Menke 2018].

Collectively, the data from the 25 reported patients reported so far support the existence of 'exon 30/31 CREBBP missense variants syndrome', which is distinct from RTS or has only partial overlap with RTS. Importantly, our report indicates that the spectrum of the phenotypes within this cohort is wide and possible genotype-phenotype correlations that need further substantiation with larger studies. Discovery of these variants further expands the catalogue of developmental disorders caused by defects in chromatin remodelling, covalent histone modifications and histone tail acetylation [Deciphering Developmental Disorders Study, 2017; Gannon et al., 2015; Faundes et al., 2018].

Accurate genetic diagnosis guides management, surveillance and treatment options, and unlocks access to relevant medical literature, information on prognosis and disorder-specific support groups for the family and medical professionals [Wright et al., 2018]. The architecture of the information system and support groups in rare disease is underpinned by disease names. Hence, providing a meaningful concise name for a diagnosis is of vital importance. For us to label the patients described here (especially patient \#2) with 'RTS1' would be misleading. The alternative name of 'exon 31 CREBBP missense variant syndrome' is cumbersome for clinical use. We, therefore, propose the name of Menke-Hennekam syndrome for the 'non- (or atypical) RTS phenotypes caused by missense variants in exon 30 and 31 of $C R E B B P^{\prime}$ [after the first and last authors of Menke et al., 2016]. We recognise that even within this eponymous designation there exists a phenotypic spectrum or even 
distinct phenotypes. However, this new umbrella term provides an appropriate balance between 'lumping and splitting' of phenotypes caused by CREBBP variants [Biesecker Leslie G., 2008]. This new name will also help in focusing future biological and translational studies.

\section{ACKNOWLEDGMENTS}

We thank the patients and their families. 


\section{REFERENCES}

Biesecker Leslie G. 2008. Lumping and splitting: molecular biology in the genetics clinic. Clinical Genetics 53: 3-7.

Cuvertino S, Stuart HM, Chandler KE, Roberts NA, Armstrong R, Bernardini L, Bhaskar S, Callewaert B, Clayton-Smith J, Davalillo CH, Deshpande C, Devriendt K, Digilio MC, Dixit A, Edwards M, Friedman JM, Gonzalez-Meneses A, Joss S, Kerr B, Lampe AK, Langlois S, Lennon R, Loget P, Ma DYT, McGowan R, Des Medt M, O'Sullivan J, Odent S, Parker MJ, Pebrel-Richard C, Petit F, Stark Z, Stockler-Ipsiroglu S, Tinschert S, Vasudevan P, Villa O, White SM, Zahir FR, Woolf AS, Banka S. 2017. ACTB Loss-of-Function Mutations Result in a Pleiotropic Developmental Disorder. The American Journal of Human Genetics 101: 1021-1033.

Deciphering Developmental Disorders Study. 2017. Prevalence and architecture of de novo mutations in developmental disorders. Nature 542: 433-438.

Dutto I, Scalera C, Prosperi E. 2018. CREBBP and p300 lysine acetyl transferases in the DNA damage response. Cellular and Molecular Life Sciences 75: 1325-1338.

Faundes V, Newman WG, Bernardini L, Canham N, Clayton-Smith J, Dallapiccola B, Davies SJ, Demos MK, Goldman A, Gill H, Horton R, Kerr B, Kumar D, Lehman A, McKee S, Morton J, Parker MJ, Rankin J, Robertson L, Temple IK, Banka S. 2018. Histone Lysine Methylases and Demethylases in the Landscape of Human Developmental Disorders. The American Journal of Human Genetics 102: 175-187.

Gannon T, Perveen R, Schlecht H, Ramsden S, Anderson B, Kerr B, Day R, Banka S, Suri M, Berland S, Gabbett M, Ma A, Lyonnet S, Cormier-Daire V, Yilmaz R, Borck G, Wieczorek D, Anderlid B-M, Smithson S, Vogt J, Moore-Barton H, Simsek-Kiper PO, Maystadt I, Destrée A, Bucher J, Angle B, Mohammed S, Wakeling E, Price S, Singer A, Sznajer Y, Toutain A, Haye D, Newbury-Ecob R, Fradin M, McGaughran J, Tuysuz B, Tein M, Bouman K, Dabir T, Van den Ende J, Luk HM, Pilz DT, Eason J, Davies S, Reardon W, Garavelli L, Zuffardi O, Devriendt K, Armstrong R, Johnson D, Doco-Fenzy M, Bijlsma E, Unger S, Veenstra-Knol HE, Kohlhase J, Lo IF, DDD study, Smith J, Clayton-Smith J. 2015. Further delineation of the KAT6B molecular and phenotypic spectrum. Eur J Hum Genet 23: 1165-1170.

Hennekam RCM. 2006. Rubinstein-Taybi syndrome. European Journal of Human Genetics 14: 981985.

Martinelli S, Krumbach OHF, Pantaleoni F, Coppola S, Amin E, Pannone L, Nouri K, Farina L, Dvorsky R, Lepri F, Buchholzer M, Konopatzki R, Walsh L, Payne K, Pierpont ME, Vergano SS, Langley KG, Larsen D, Farwell KD, Tang S, Mroske C, Gallotta I, Di Schiavi E, della Monica M, Lugli L, Rossi C, Seri M, Cocchi G, Henderson L, Baskin B, Alders M, Mendoza-Londono R, Dupuis L, Nickerson DA, Chong JX, Meeks N, Brown K, Causey T, Cho MT, Demuth S, Digilio MC, Gelb BD, Bamshad MJ, Zenker M, Ahmadian MR, Hennekam RC, Tartaglia M, Mirzaa GM. 2018. Functional Dysregulation of CDC42 Causes Diverse Developmental Phenotypes. The American Journal of Human Genetics 102: 309-320.

Menke LA, van Belzen MJ, Alders M, Cristofoli F, The DDD Study, Ehmke N, Fergelot P, Foster A, Gerkes EH, Hoffer MJV, Horn D, Kant SG, Lacombe D, Leon E, Maas SM, Melis D, Muto V, Park S-M, Peeters H, Peters DJM, Pfundt R, van Ravenswaaij-Arts CMA, Tartaglia M, Hennekam RCM. 2016. CREBBP mutations in individuals without Rubinstein-Taybi syndrome phenotype. Am. J. Med. Genet. 170: 2681-2693.

Menke LA, The DDD study, Gardeitchik T, Hammond P, Heimdal KR, Houge G, Hufnagel SB, Ji J, Johansson S, Kant SG, Kinning E, Leon EL, Newbury-Ecob R, Paolacci S, Pfundt R, Ragge NK, Rinne T, Ruivenkamp C, Saitta SC, Sun Y, Tartaglia M, Terhal PA, van Essen AJ, Vigeland MD, 
Xiao B, Hennekam RC. 2018. Further delineation of an entity caused by CREBBP and EP300 mutations but not resembling Rubinstein-Taybi syndrome. American Journal of Medical Genetics Part A 176: 862-876.

Petrif F, Giles RH, Dauwerse HG, Saris JJ, Hennekam RCM, Masuno M, Tommerup N, van Ommen G-JB, Goodman RH, Peters DJM, Breuning MH. 1995. Rubinstein-Taybi syndrome caused by mutations in the transcriptional co-activator CBP. Nature 376: 348-351.

Reijnders MRF, Ansor NM, Kousi M, Yue WW, Tan PL, Clarkson K, Clayton-Smith J, Corning K, Jones JR, Lam WWK, Mancini GMS, Marcelis C, Mohammed S, Pfundt R, Roifman M, Cohn R, Chitayat D, Millard TH, Katsanis N, Brunner HG, Banka S. 2017. RAC1 Missense Mutations in Developmental Disorders with Diverse Phenotypes. The American Journal of Human Genetics 101: 466-477.

Stoyle G, Banka S, Langley C, Jones EA, Banerjee I. 2018. Growth hormone deficiency as a cause for short stature in Wiedemann-Steiner Syndrome. Endocrinol Diabetes Metab Case Rep 2018.

Wiley S, Swayne S, Rubinstein JH, Lanphear NE, Stevens CA. 2003. Rubinstein-Taybi syndrome medical guidelines. American Journal of Medical Genetics Part A 119A: 101-110.

Wright CF, FitzPatrick DR, Firth HV. 2018. Paediatric genomics: diagnosing rare disease in children. Nature Reviews Genetics. 


\section{TABLES}

Table 1: Comparison of clinical features of our patients with corresponding patients reported by Menke et al

\begin{tabular}{|c|c|c|c|c|c|c|c|c|c|}
\hline \multirow{2}{*}{\begin{tabular}{|l|} 
Variant \\
Patients \\
\end{tabular}} & \multirow{2}{*}{$\begin{array}{c}\text { c.5357G }>A \\
\text { p. } \\
\text { (Arg1786His } \\
\text { ) } \\
\text { Patient \#1 }\end{array}$} & \multirow{2}{*}{\begin{tabular}{|c|} 
c.5357G>C \\
p. \\
(Arg1786Pro \\
) \\
Patient \#3 \\
\end{tabular}} & \multicolumn{6}{|c|}{$\begin{array}{c}c .5602 C>T \\
\text { p. (Arg1868Trp) }\end{array}$} & \multirow{2}{*}{$\begin{array}{c}\text { c.5354G }>A \\
\text { p.(Cys1785Tyr } \\
\text { ) } \\
\text { Patient \#3 } \\
\end{array}$} \\
\hline & & & Patient \#2 & Patient \#9 & Patient \#10 & $\mathrm{C} 17$ & C18 & C19 & \\
\hline Reference & This report & $\begin{array}{l}\text { Menke et al } \\
2016\end{array}$ & This report & $\begin{array}{l}\text { Menke et } \\
\text { al } 2016\end{array}$ & $\begin{array}{l}\text { Menke et } \\
\text { al } 2016\end{array}$ & $\begin{array}{l}\text { Menke et } \\
\text { al } 2018\end{array}$ & $\begin{array}{l}\text { Menke et } \\
\text { al } 2018\end{array}$ & $\begin{array}{l}\text { Menke et } \\
\text { al } 2018\end{array}$ & This report \\
\hline $\begin{array}{l}\text { Prenatal growth } \\
\text { retardation }\end{array}$ & - & - & + & - & + & - & - & + & + \\
\hline $\begin{array}{l}\text { Postnatal growth } \\
\text { retardation }\end{array}$ & + & - & + & + & - & + & - & + & + \\
\hline Microcephaly & + & - & + & + & + & + & - & - & + \\
\hline Developmental delay & $\begin{array}{l}\text { Moderate- } \\
\text { severe }\end{array}$ & Severe & Severe & Severe & Severe & Severe & Severe & \begin{tabular}{|l|} 
Not \\
available \\
\end{tabular} & + \\
\hline $\begin{array}{l}\text { Autism/autism-like } \\
\text { behaviours }\end{array}$ & + & + & $?$ & + & $\begin{array}{l}\text { Not } \\
\text { available }\end{array}$ & - & + & $\begin{array}{l}\text { Not } \\
\text { available }\end{array}$ & - \\
\hline Epilepsy & - & $+/-$ & - & - & + & - & - & - & - \\
\hline $\begin{array}{l}\text { Cardiovascular } \\
\text { abnormalities }\end{array}$ & - & - & - & - & - & - & - & - & \\
\hline $\begin{array}{l}\text { Urinary tract } \\
\text { abnormalities }\end{array}$ & - & - & + & - & - & + & + & + & \\
\hline Scoliosis & - & - & + & - & - & - & + & + & - \\
\hline High palate & $?$ & - & $?$ & + & - & + & + & + & - \\
\hline Micrognathia & - & + & - & - & - & + & - & + & - \\
\hline Low-set ears & + & + & + & + & + & + & + & + & - \\
\hline Broad thumbs & Mild & - & - & - & - & & & & \\
\hline Angulated thumbs & - & - & - & - & - & & & & - \\
\hline Broad halluces & - & $+/-$ & - & - & - & + & - & + & - \\
\hline
\end{tabular}




\begin{tabular}{|c|c|c|c|c|c|c|c|c|c|}
\hline Clinodactyly & - & $?$ & - & + & - & + & + & - & - \\
\hline Syndactyly & - & - & - & $4-5$ & - & + & - & - & - \\
\hline $\begin{array}{l}\text { Fibular deviation of } \\
\text { distal phalanx halluces }\end{array}$ & - & + & - & + & + & + & - & + & + \\
\hline Hypertrichosis & + & - & - & - & - & & & & + \\
\hline Highly arched eyebrows & + & - & - & + & - & + & - & - & - \\
\hline Long eyelashes & + & + & - & - & - & - & + & - & + \\
\hline Ptosis & - & - & - & + & + & + & - & + & $+($ left $)$ \\
\hline Squint & - & + & + & + & - & & & & - \\
\hline $\begin{array}{l}\text { Down-slanted palpebral } \\
\text { fissures }\end{array}$ & + & + & - & - & - & - & - & - & - \\
\hline Epicanthi & - & - & - & - & - & - & - & - & - \\
\hline Hypertelorism & - & - & + & + & + & + & + & + & - \\
\hline Depressed nasal ridge & - & - & $+\quad 20$ & + & + & + & - & + & - \\
\hline Convex nasal ridge & - & + & - & - & - & & & & + \\
\hline Short nose & - & - & + & 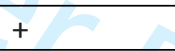 & + & + & + & + & + \\
\hline Broad nasal tip & + & + & + & 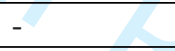 & + & & & & + \\
\hline Short columella & - & - & + & + & + & + & + & + & - \\
\hline Low hanging columella & - & + & - & - & $-\quad 1$ & & & & + \\
\hline Anteverted nares & - & - & + & + & + & + & - & + & - \\
\hline Full cheeks & - & - & + & - & + & + & + & + & - \\
\hline Philtrum & - & - & Long, deep & Long, deep & Long, deep & Long, deep & - & Long & Long, deep \\
\hline Low-set ears & + & + & + & + & + & + & + & + & - \\
\hline Protruding upper ears & + & + & + & + & + & + & - & + & - \\
\hline Grimacing smile & - & - & - & - & - & & & & \\
\hline Other & $\begin{array}{l}\text { Cryptorchidi } \\
\text { sm }\end{array}$ & $\begin{array}{l}\text { Cryptorchidi } \\
\text { sm }\end{array}$ & - & - & - & - & - & - & $\begin{array}{l}\text { Hemangiomas, } \\
\text { talipes varus } \\
\text { with } \\
\text { overlapping } \\
\text { toes, delayed } \\
\text { tooth eruption }\end{array}$ \\
\hline
\end{tabular}




\section{FIGURE LEGENDS}

\section{Figure 1: Clinical features of patients described in this study}

A and B) Patient \#1 at 3y $3 \mathrm{~m}$ and 5y $3 \mathrm{~m}$ of ages respectively. Note chaotic slightly arched eyebrows, a square tip to his nose, normal columella, large prominent ears and absence of characteristic grimace of RubensteinRubinsteinTaybi syndrome.

C) Patient \#2 at 7 months of age. Note hypertelorism, broad eyebrows, upslanting palpebral fissures, long deep philtrum, large mouth with middle alveolar notch; small chin; low-set ears;. Compare with patients \#9 and \#10 reported in Menke et al. 2016 and C17, 18 and 19 in Menke et al. 2018 who all have the same variant.

D) Patient 3 at 25 months of age. Note the mildly hirsute forehead with-broad eyebrows, left ptosis; and long deep philtrum.

E, F, and G) MRI Brain of patient \#2 at 4 months of age: Axial T1WI (E) and axial T2WI (F) show bilateral subependymal grey matter heterotopia along the temporal horns of the lateral ventricles. Sagittal T1WI (G) demonstrates short small in caliber corpus callosum.

H) MRI brain of patient 3 at 25 months of age shows bilateral staphlylomas (posterior uveal protrusions). 


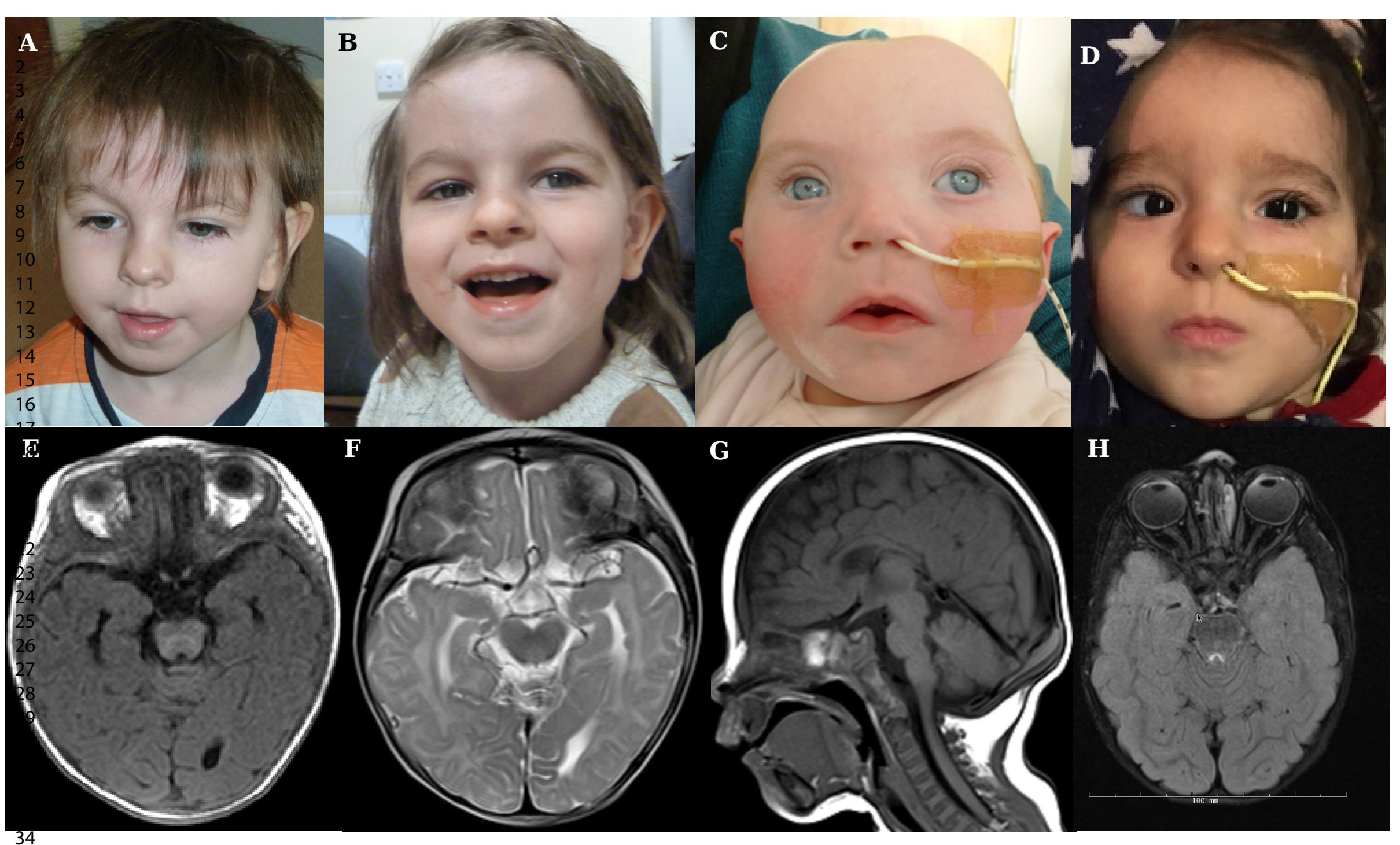

John Wiley \& Sons, Inc. 